Article

\title{
Combined Effects of Hillslope-Concentrated Flows and Riverine Stream Waves on Soil Erosion in the Reservoir Riparian Zone
}

\author{
Yuhai Bao ${ }^{1}$, Yantong Yu ${ }^{1,2}$, Qiang Tang ${ }^{3, *}$, Xiubin $\mathrm{He}^{1}$, Jie Wei ${ }^{4}$, Yunhua $\mathrm{Hu}^{5}$ and Jinlin $\mathrm{Li}^{6}$ \\ 1 Key Laboratory of Mountain Surface Processes and Ecological Regulation, Institute of Mountain Hazards and \\ Environment, Chinese Academy of Sciences, Chengdu 610041, China; byh@imde.ac.cn (Y.B.); \\ yuyantong21@mails.ucas.ac.cn (Y.Y.); xiubinh@imde.ac.cn (X.H.) \\ 2 University of Chinese Academy of Sciences, Beijing 100049, China \\ 3 Chongqing Jinfo Mountain Karst Ecosystem National Observation and Research Station, School of \\ Geographical Sciences, Southwest University, Chongqing 400715, China \\ 4 Geography and Tourism College, Chongqing Normal University, Chongqing 400047, China; \\ wei_jie@mail.ucas.ac.cn \\ 5 The Third Surveying and Mapping Engineering Institute in Sichuan Province, Chengdu 610500, China; \\ huyunhua1@163.com \\ 6 Key Laboratory of Reservoir Aquatic Environment, Chongqing Institute of Green and Intelligent Technology, \\ Chinese Academy of Sciences, Chongqing 400714, China; chinlin_lee@sina.com \\ * Correspondence: qiangtang@swu.edu.cn
}

check for updates

Citation: Bao, Y.; Yu, Y.; Tang, Q.; He, X.; Wei, J.; Hu, Y.; Li, J. Combined Effects of Hillslope-Concentrated Flows and Riverine Stream Waves on Soil Erosion in the Reservoir Riparian Zone. Water 2021, 13, 3465.

https://doi.org/10.3390/w13233465

Academic Editor: Dominic E. Reeve

Received: 30 October 2021

Accepted: 5 December 2021

Published: 6 December 2021

Publisher's Note: MDPI stays neutral with regard to jurisdictional claims in published maps and institutional affiliations.

Copyright: (c) 2021 by the authors. Licensee MDPI, Basel, Switzerland. This article is an open access article distributed under the terms and conditions of the Creative Commons Attribution (CC BY) license (https:// creativecommons.org/licenses/by/ $4.0 /)$.

\begin{abstract}
During the exposed season, the water level fluctuation zone of the Three Gorges Reservoir has suffered from hillslope-concentrated flows and riverine stream waves, which considerably complicates the processes and magnifies the rate of bank erosion. This study depicts the forms and patterns of integrated bank erosion in this reservoir marginal landscape, decouples the evolutionary processes involved, explores the underlying mechanisms, and quantifies the magnitude through a case study on a fine-grained sandy bank. Hillslope-concentrated flows over rainfall storm events developed continuous gullies starting from uplands and extending throughout the entire slope of the reservoir bank, characterized by relatively larger depths and widths compared with discontinuous gullies on the lower slope developed by riverine stream waves.
\end{abstract}

Keywords: bank erosion; hillslope-concentrated flow; wave action; water level fluctuation zone; Three Gorges Reservoir

\section{Introduction}

The riparian zone is defined as all stream-adjacent landforms likely to be inundated or saturated by riverine overbank discharges [1]. It delivers dynamic and complex interactions with river channels via bank erosion and sediment deposition (Figure 1), acting as an important structural and functional component of river systems [2-4]. More specifically, bank erosion has been recognized as a contributor to suspended sediment load transported by global rivers [5,6]. For instance, bank erosion was found to contribute to $5-15 \%$ of the suspended sediment load in British rivers, and the proportion was even larger than $40 \%$ in many catchments [7]. A three-year field measurement regime indicated over $90 \%$ of the total sediment load in a $486 \mathrm{~km}^{2}$ catchment in Denmark originating from bank erosion [8]. Fine-grained suspended sediment in rivers has many negative consequences to stream ecology (e.g., fish reproduction, benthic community, and rotifers density), water quality (diffuse contaminants input, mobilization, and transfer), and flooding and sedimentation risk $[9,10]$. Lateral adjustment of river channels following bank erosion threatens the sustainable use of fertile upland agricultural lands, degrades riparian landscapes, disrupts vegetation succession by the loss of favorable habitat, and impairs ecosystem services such 
as biodiversity maintenance, bank stabilization, sediment retaining, diffuse agricultural contaminants filtering and abatement, and runoff regulation [11-13].

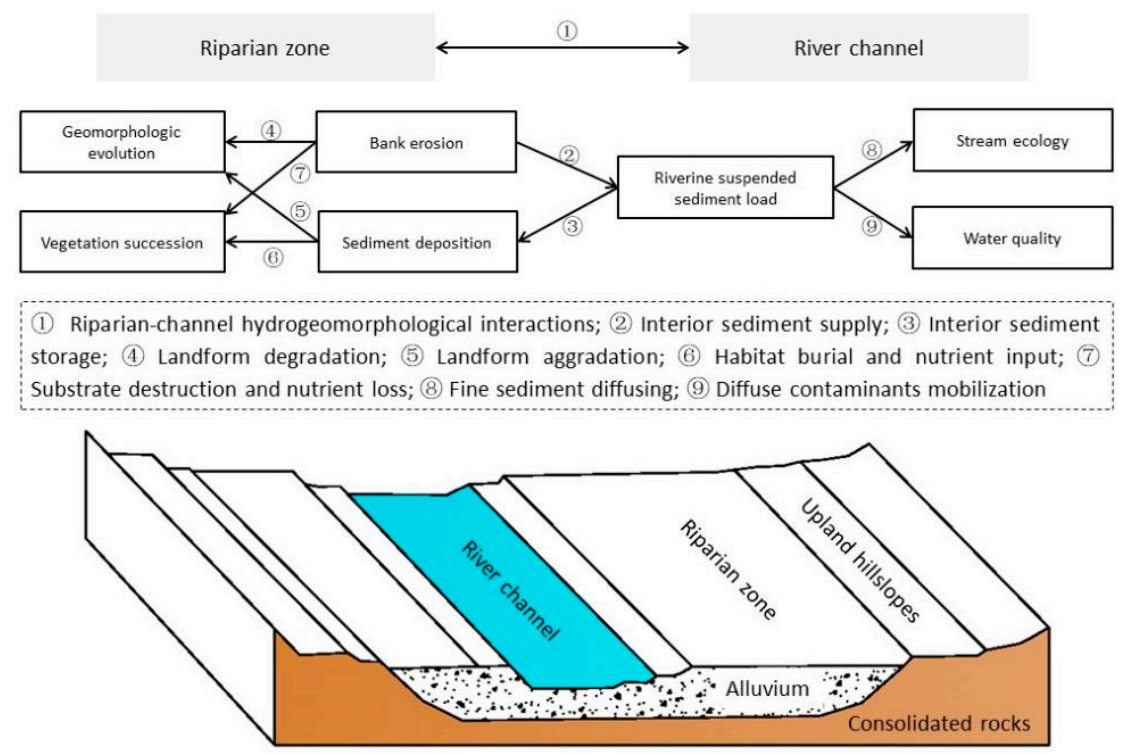

Figure 1. The components of interactions between the riparian zone and river channel (partly modified from [14]).

The riparian zone of the Three Gorges Reservoir is a unique artificial landscape created by flow regulation following regular dam operations, where bank erosion differs substantially from that in the conventional natural riparian zone of unregulated rivers in terms of driving forces, forms, evolutionary processes, and magnitude [15]. The combination of hillslope-concentrated flows and riverine stream waves over the exposed season has complicated the processes and magnified the rate of soil erosion in the reservoir marginal landscape. Loss of original terrestrial vegetation by extreme flooding stress further facilitates soil erosion, given the key role that vegetation plays in bank stabilization through land surface protection by aboveground biomass and soil consolidation by root structure. Change of soil geophysical properties makes the soil bank more susceptible to erosion by a collection of external forces. Given the key role that the reservoir riparian zone plays as a critical buffer strip or ecological corridor, knowledge of the form, evolutionary processes, mechanisms, and magnitude of soil erosion is critical for restoration purposes.

Our previous study carried out field measurements using traditional erosion pins and reported the temporal trend of total bank erosion rates since the formation of this landscape and its spatial variability between the mainstream and tributary reaches [16]. In this study, we describe the forms and patterns of integrated bank erosion in the riparian zone of the Three Gorges Reservoir, analyze the evolutionary processes involved, explore the underlying mechanisms, and quantify the magnitude, through a case study performed on a fine-grained sandy bank. Major results obtained may enhance our current knowledge on integrated bank erosion in the reservoir riparian zone, which has been significantly disturbed by flow regulation, and provide implications for potential measures for bank consolidation and vegetation restoration.

\section{Methodology}

\subsection{Study Area}

The Three Gorges Dam on the upper Yangtze River has a full storage capacity of 34.3 billion $\mathrm{m}^{3}$ and a flood regulation capacity of 22.4 billion $\mathrm{m}^{3}$, which allows it to supply multiple services including hydropower generation, flood control, and navigation improvement. The Three Gorges Reservoir extends $661 \mathrm{~km}$ long and impounds a water area of $1080 \mathrm{~km}^{2}$ (Figure 2). A specific operational strategy defined as "impounding clean 
water and draining turbid water" has been adopted, generating a specific schedule for water level fluctuating. On a hydrological year basis, water level fluctuates between the base level of $145 \mathrm{~m}$ in the rainy season (May-September) and the peak level of $175 \mathrm{~m}$ in the dry season (October-April). A unique reservoir riparian zone with a vertical height of $30 \mathrm{~m}$ and a total area of $349 \mathrm{~km}^{2}$ has been created [16-19].

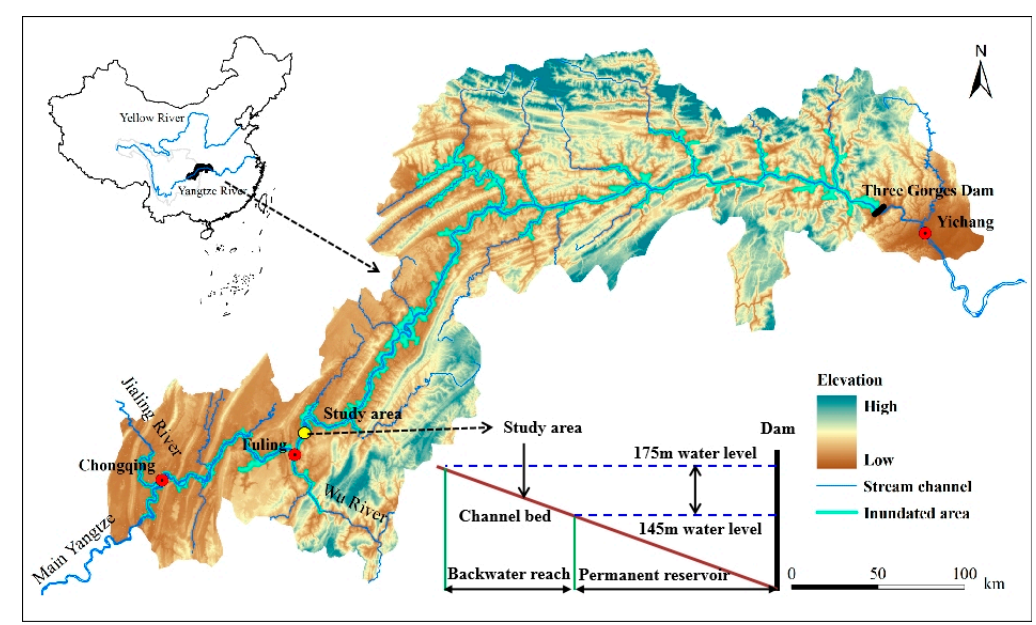

Figure 2. Map of the Three Gorges Reservoir and location of study area.

The Three Gorges Reservoir area is dominated by northeast-southwest paralleling mountains and valleys (Figure 2). Regional landform is dominated by hills and low mountains in the western-central section, where the channel width is large and slope gradient is low, and by high mountains in the eastern section, where channels are narrow with steep slopes and bare rocks. The study area is located in the backwater reach of the Three Gorges Reservoir (Figure 2). The selected riparian reach is a fine-grained sandy bank. This area has a humid subtropical monsoon climate, with an annual precipitation of $1072 \mathrm{~mm}$, a significant portion of which falls during the rainy season from May to September.

\subsection{Field Measurement}

Field measurement was carried out in late May 2013, when local riverine water level was kept at around $152 \mathrm{~m}$ and river channel exhibited a natural flow state. Previously, a storm event with daily precipitation larger than $50 \mathrm{~cm}$ and a natural flood event with water level rising to $155 \mathrm{~m}$ has occurred (Figure 3), giving rising to the cooccurrence of hillslopeconcentrated flow erosion and fluvial wave entrainment in the selected riparian zone.

A typical observation plot (with length $5 \mathrm{~m}$ and width $5 \mathrm{~m}$ ) was set up in the selected riparian zone. The length $(L)$, depth $(D)$, and width $(W)$ of the gully were measured by a measuring tapes and ranging poles. The measuring section was set at $0.5 \mathrm{~m}$ intervals in each of the erosion gullies. The gully length was obtained by multiplying the number of intervals points by 0.5 [20]. For measuring the widths of the bottom and shoulders, each interval points were successive marked by a ranging pole, and then the gully bottom and shoulder width were measured with the measuring tape at each point. The mean width $(W)$ of each gully was calculated using the following formula [20]:

$$
\begin{gathered}
\text { Mean bottom width, } W_{b}=\frac{\text { Sum of bottom width readings }}{\text { Number of interval points }} \\
\text { Mean shoulder width, } W_{s}=\frac{\text { Sum of shoulder width readings }}{\text { Number of interval points }} \\
\text { Mean gully width, } W=\frac{W_{b}+W_{s}}{2}
\end{gathered}
$$


The average gully depth $(D)$ was estimated using the following procedures: (1) placing one of the poles at the deepest part of the gully floor, (2) measuring the bed and shoulder widths at the same interval point, (3) deploying the tape at ground level and stretching across the gully channel over the ranging pole, and (4) using the below equation to calculate $D$ value.

$$
D=\frac{\text { Sum of interval depths }}{\text { Number of interval points }}
$$

The volume of each gully $(V)$ was calculated by the following formula presented by Kaczmarek (2016) [21]:

$$
V=\sum\left(\frac{S_{i}+S_{i+1}}{2} \times L_{i-i+1}\right)
$$

where $V$ is gully volume, $L_{i-i+1}$ is distance between two adjacent profiles, and $S_{i}+S_{i+1}$ is cross-sectional area of the measured profiles $i$ and $i+1$.

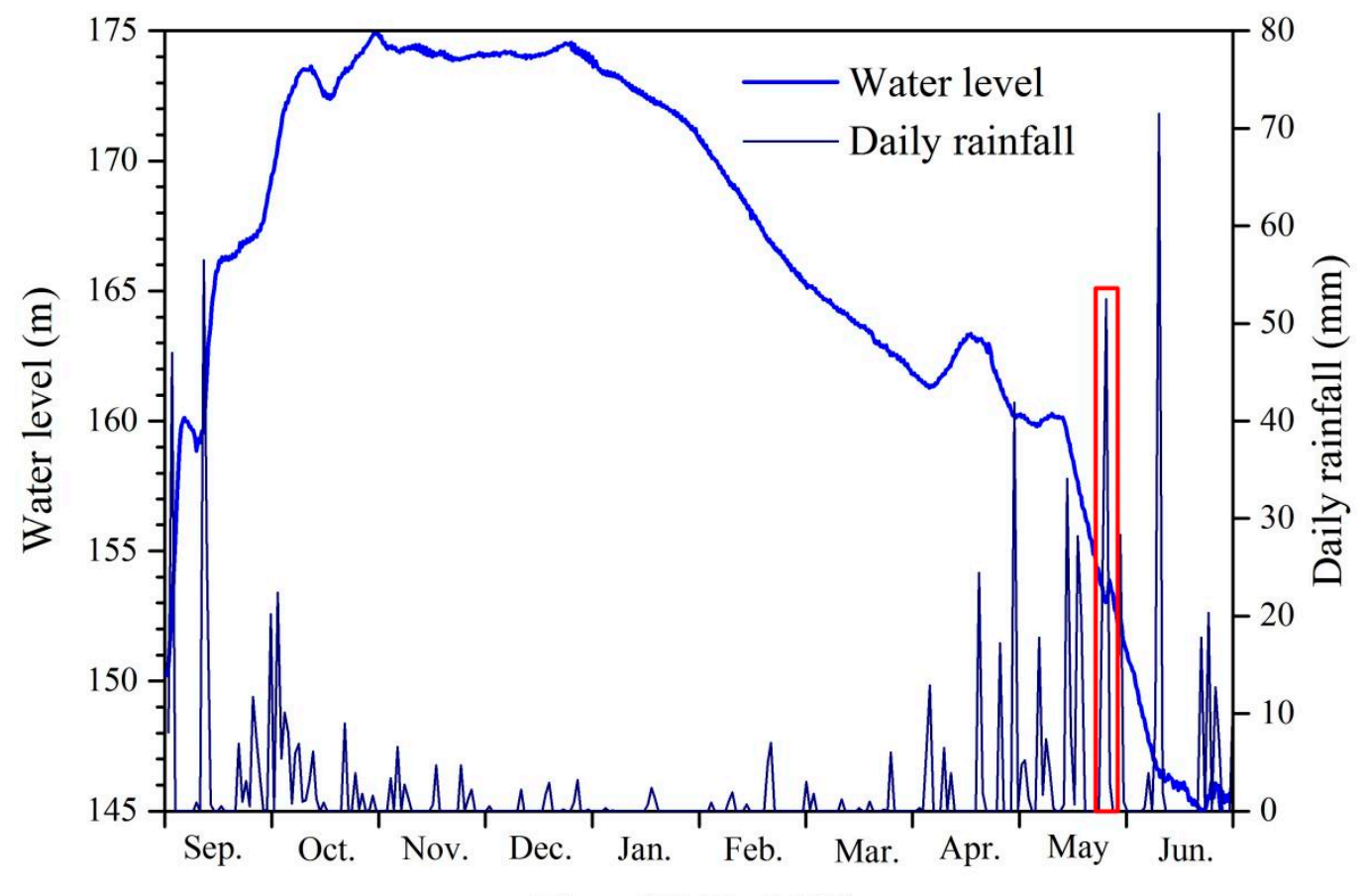

Time (2012-2013)

Figure 3. Change of reservoir water level and daily rainfall over the hydrological year of 2012-2013, and the study period is indicated using a red rectangle.

\subsection{Data Acquisition}

The daily water level operated by the Three Gorges Dam and daily rainfall in the study area are depicted in Figure 3. The data of daily rainfall and reservoir water level were assembled to interpret potential function of extreme storms and stream flood pulses on gully formation in the study riparian zone. Daily data of water level (inundation height) of the Three Gorges Reservoir was collected from the China Three Gorges Corporation (www.ctgpc.com.cn (accessed on 31 December 2013)). Daily rainfall recorded at nearby Fengdu Station is available from the National Meteorological Information Center (http: / / cdc.cma.gov.cn (accessed on 31 December 2013)).

\section{Results}

\subsection{Morphologic Features of Soil Erosion in the Reservoir Riparian Zone}

Our field visit showed that the landform of the riparian zone was homogeneous due to sedimentation in the previous inundation period by reservoir impoundment, and bank erosion was mainly performed in the form of gullying. Two categories of gullies can be 
generally identified based on their morphological features, showing different lengths and cross-section profiles. Two continuous gullies were observed with lengths ranging from 38 to $46 \mathrm{~m}$, which started from upland hillslopes, extended throughout the entire slope of the riparian zone, and collected with the reservoir regime (Figure 4a). Six discontinuous gullies were found with lengths ranging from 3.1 to $3.8 \mathrm{~m}$ occurring in the lower portions of the riparian zone (Figure $4 \mathrm{~b}$ ). The cross-section profile of continuous gullies was characterized by relatively larger depths varying between $0.3-1.9 \mathrm{~m}$ and lower widths varying between 0.2-0.8 $\mathrm{m}$, compared with that of the discontinuous gullies, with depths and widths varying between $0.1-0.4 \mathrm{~m}$ and $0.4-1.6 \mathrm{~m}$, respectively (Table 1 ).

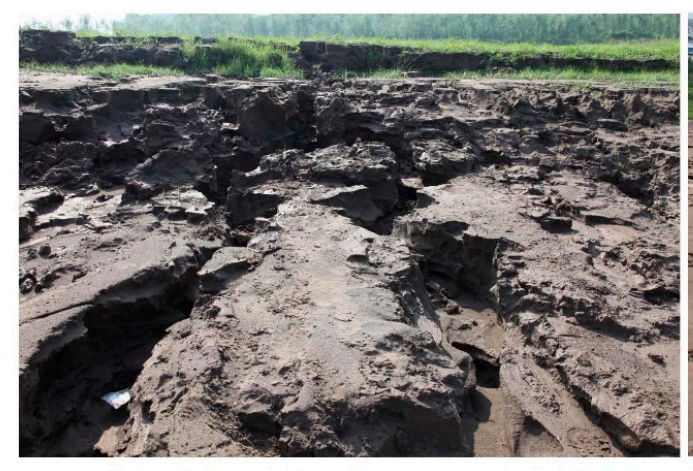

a

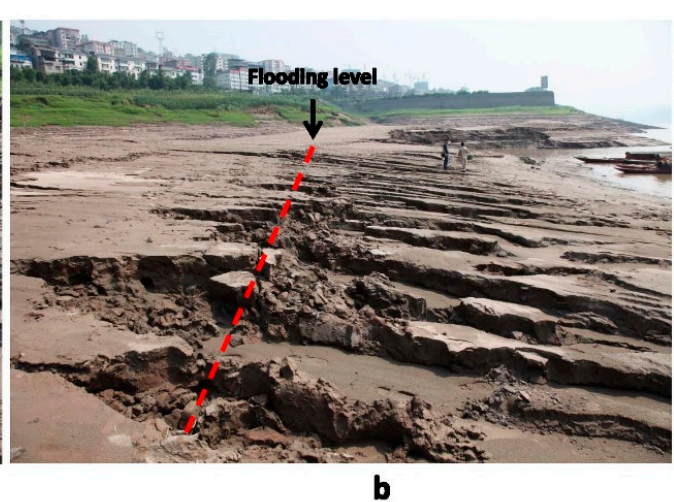

b

Figure 4. Photographs: (a) continuous gullies start from upland hillslopes and extend throughout the entire slope, (b) discontinuous gullies occur in lower portions, and slope gradient transition around the flooding level.

Table 1. Morphologic features of gullies developed in the water level fluctuation zone.

\begin{tabular}{ccccc}
\hline Morphologic Features & Number & Lengths (m) & Widths (m) & Depths (m) \\
\hline Continuous gullies & 2 & $38-46$ & $0.2-0.8$ & $0.3-1.9$ \\
Discontinuous gullies & 6 & $3.1-3.8$ & $0.4-1.6$ & $0.1-0.4$ \\
\hline
\end{tabular}

A distinctive line showing the deposition of woody debris indicates the peak level of a previous overbank flood event (Figure $4 b$ ). Sheeting occurs on the inter-gully surface which was subjected to repeated stream wave flushing during the flood. Surface erosion caused loss of large quantity of bank materials, leading to a larger bed slope compared with that in the riparian zone without flooding disturbance (Figure $4 b$ ).

\subsection{The Evolutionary Process of Bank Erosion in the Riparian Zone}

The development of continuous and discontinuous gullies was driven by different forcing agents and went through contrasting processes. Original drainage networks in the riparian zone remained unmanaged after water inundation and were gradually silted by sediments and, consequently, the draining capacity was lost. Concentrated flows collected from upland hillslopes in storms events directly entered the riparian zone. During the initial runoff period, flow path in the riparian zone migrated frequently when the shear stress was still below the erosion threshold of the bank. Flow path would be fixed if denudation force exceeds resistance strength, and continuous gullies were initiated. A large quantity of sediments was detached through subsequent processes of gully wall failure and bed scouring, creating discontinuous gullies characterized by relatively high depths and narrow widths.

The discontinuous gullies were initiated in the riparian zone where the erosive force of concentrated flows exceeds the resistance force of bank material, and further developed by riverine stream waves over a flood period.

Concentrated overland flows and natural flood pulses simultaneously operated on bank erosion in the riparian zone. The processes of gully initiation and development 
which led to significant bank erosion are interpreted in Figure 5. Originally, the gullies were initiated by concentrated shallow flows generated in the upper reach of the riparian zone during the extreme storm event. Fluvial entrainment had greatly contributed to the development of the gullies through widening and downslope mass movement. The presence of concentrated overland flows subsequently contributed to head-cutting and, thus, up-moving of gullies head. This can explain large gullies with head at relatively high elevation level (Figure 6).

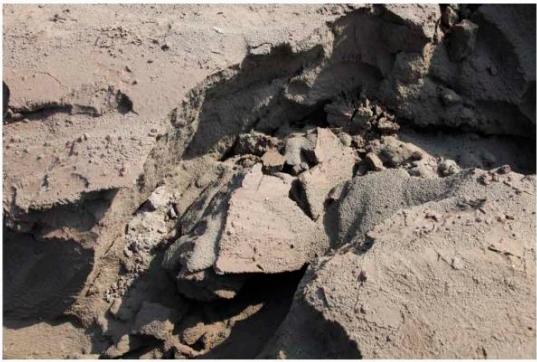

$\mathbf{a}$

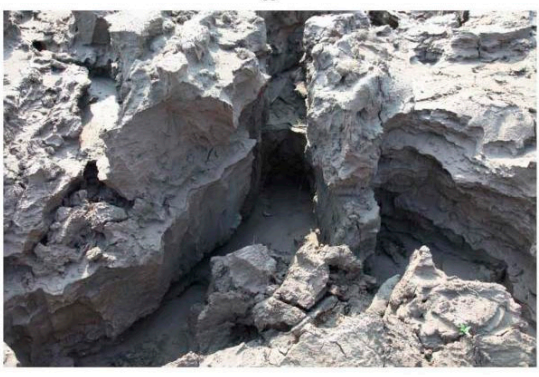

c

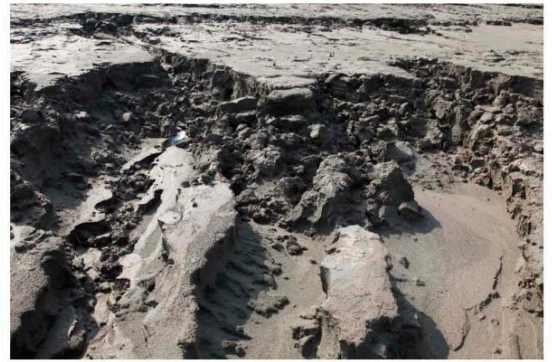

b

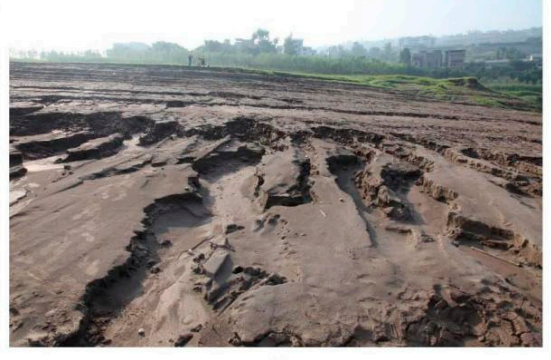

d

Figure 5. The evolutionary processes for discontinuous gullies in the riparian zone: (a) wall failure, (b) head retreat, (c) bed deepening, and (d) width enlargement.

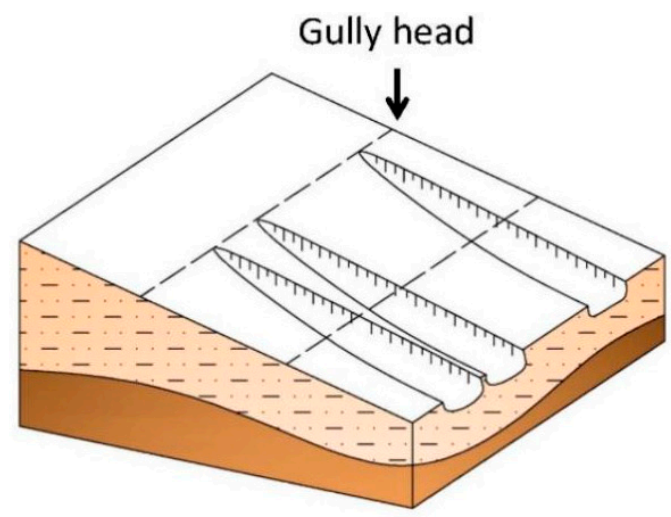

a

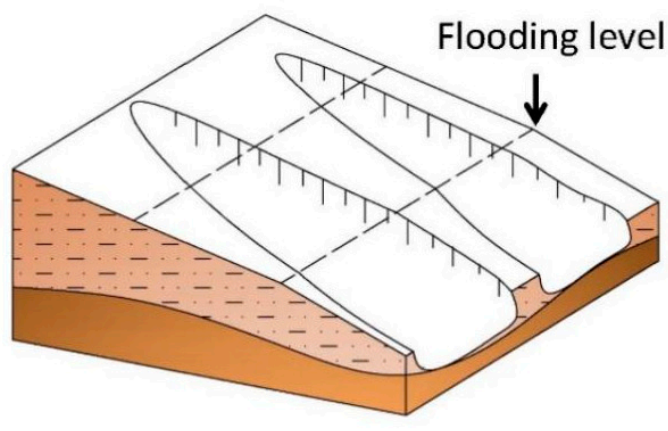

b

Figure 6. Gully development by head movement, width enlargement, and inter-gully area sheeting below the flooding level: (a) gully initiation, and (b) gully development.

Furthermore, it can be observed that the averaged gradient of the slopes above the flood level was relatively larger than that of the slope below the flood level. This means that the inter-gully area had been degraded due to erosion caused by stream forces. Consequently, the processes that contributed to the occurrence of gullies in the lower parts of the riparian zone include gullying, scouring, mass failure, sheeting, and sediment transport. 


\subsection{Quantifying the Magnitude of Bank Erosion in the Riparian Zone}

In this study, a typical observation plot was set up in the reservoir riparian zone, and six gullies in total were studied, and parameters analyzed. Table 2 shows the parameters of both gullies in the observation plot. From the observations, one can notice that the gullies were extremely developed, an area which accounts for $52.96 \%$ of the observing area. The depth and width have a significant difference between the two gullies, while there was no significant difference in the mean bed gradient ( $p$-value of statistical significance $<0.05$ ). The mean gully width in the study area ranges from $0.30 \mathrm{~m}$ to $0.68 \mathrm{~m}$, while the mean depth ranges from $0.10 \mathrm{~m}$ to $0.21 \mathrm{~m}$. The gully was dominated by type of wide-shallow, and the ratio of width to depth was ranged from 2.95 to 3.75, with an average ratio of 3.31 . The volume of total gully erosion was 1.01 cubic meters in the typical observation plot. It was hence estimated that the 0.040 cubic meters of soil may be supplied to the stream per square meter of observation plot by the gully erosion.

Table 2. Bank erosion rate estimated by measuring the size of gullies.

\begin{tabular}{|c|c|c|c|c|c|c|c|}
\hline $\begin{array}{l}\text { Map Area } \\
\left(\mathrm{m}^{2}\right)\end{array}$ & $\begin{array}{l}\text { Surface Area } \\
\qquad\left(\mathrm{m}^{2}\right)\end{array}$ & $\begin{array}{c}\text { Gully } \\
\text { Length (m) }\end{array}$ & Mean $W(\mathrm{~m})$ & Mean $D(\mathrm{~m})$ & W/D & $\begin{array}{l}\text { Gradient } \\
(\%)\end{array}$ & $\begin{array}{c}\text { Eroded } \\
\text { Volume }\left(\mathrm{m}^{3}\right)\end{array}$ \\
\hline \multirow{6}{*}{25} & 1.36 & 2.37 & 0.45 & 0.12 & 3.75 & 16.30 & 0.096 \\
\hline & 2.67 & 3.88 & 0.62 & 0.21 & 2.95 & 16.80 & 0.21 \\
\hline & 1.35 & 3.45 & 0.30 & 0.10 & 3.00 & 16.20 & 0.085 \\
\hline & 2.65 & 3.90 & 0.62 & 0.20 & 3.10 & 16.40 & 0.20 \\
\hline & 2.36 & 3.85 & 0.55 & 0.15 & 3.67 & 16.30 & 0.16 \\
\hline & 2.85 & 3.95 & 0.68 & 0.20 & 3.40 & 16.60 & 0.26 \\
\hline Total & 13.24 & 21.40 & 0.54 & 0.16 & 3.31 & 16.43 & 1.01 \\
\hline
\end{tabular}

\section{Discussion}

\subsection{The Specificity of Soil Erosion in This Reservoir Marginal Landscape}

Gully erosion is one of the major types of soil water erosion in many parts of the world [22,23]. Traditional gully erosion studies mainly focus on the hillslopes, where gullies generally form due to the scoured process in the aeolium, colluvium, eluvium, weak sedimentary rock, or other weathered rock [24]. In this study, the reservoir riparian zone gullies originate from the relatively gentle alluvial terraces in the adjacent banks of the river channel (Figure 4). Their characteristics rather agree with the description in the literature of alluvial gullies, valley-bottom gullies, and bank gullies [25-27]. Similar to the alluvial gullies [26], these gullies here have relatively young topographic characteristics, and usually cut into alluvium (Figure 4). Alluvial gullies are commonly found in large alluvial deposits along main streams or other large bodies of water such as inlets or lakes (e.g., Figure 6). Therefore, they have high sediment transport rates and are the main sources of fine suspended sediment [28]. In contrast to the gullies in the reservoir riparian zone, traditional gullies in the hillslope are not always connected directly to the channel system downstream, with the eroded sediment deposited in a floodplain or low-lying land of small valley [29]. In this case, the contribution of traditional hillslope gullies to the stream sediment transport is much less than if they were completely connected to the drainage system (i.e., riparian bank gully). Because of the lack of structural control over their lateral expansion, the riparian bank gully generally expands in longitudinal and lateral direction until it develops a new stable bed slope. In the meantime, it erodes large amounts of floodplain alluvial deposits $[26,27,30]$. In term of geomorphic features, the gullies in this study are usually as wide as deep or wider than deep (Tables 1 and 2).

Many researchers worldwide have attempted to investigate the gully retrogressive erosion rates and to quantify the eroded volumes using the repeated measures over different periods [31-34] or the remote sensing image of time series [35]. General morphology characteristics of gully channels are important for determining gully retrogressive erosion rates and soil erosion amount [31]. The accurate measurement of the geomorphological parameters of the gully is important not only for the calculation of the amount of soil 
erosion $[34,36]$ but also for understanding erosion dynamics $[31,37]$. The most commonly measured parameters are gully width, depth, length, bottom gradient, and ratios between these parameters $[31,38,39]$, and the parameters proportion (i.e., the relationship between width and depth) is an important morphology characteristic of gully cross sections [31]. Many studies have indicated that gully eroded volume $(V)$ has a positive correlation with the aspect ratio $(W / D)[20,26]$. In addition, higher $W / D$ values reveal relatively wide and shallow cross sections of the gully, while lower values indicate narrow and deep cross sections. [31,38]. The ratio of $W / D$ were reported in Table 3. W/D in each of the investigated six gullies ranged from 2.95 to 3.75 , with an average of 3.31. Based on the statistical analysis of field survey of gully dimensions, the US-SCS observed that the width of gullies formed on cohesive soils is three times their depth, while on frictional soils, the W/D ratio is 1.75 [20,31]. The results were also comparable with those reported in the Upper Yangtze River Basin and Loess Plateau [34,39], where the ratio of W/D was 0.84 to 3.52 and 0.24 to 1.47 , respectively, with an average of 1.91 and 0.79 , respectively.

Table 3. Bank erosion through gullying and sheeting processes.

\begin{tabular}{|c|c|c|c|}
\hline Forms & Processes & Agents & Water Level \\
\hline Gully & $\begin{array}{l}\text { Raindrop detachment, scouring, } \\
\text { micro-scale mass failure }\end{array}$ & $\begin{array}{l}\text { Raindrops, overland flows, } \\
\text { stream waves }\end{array}$ & $\begin{array}{c}\text { Higher water level or water level } \\
\text { fluctuation }\end{array}$ \\
\hline Inter-gully & Sheeting & Stream waves, runoff & $\begin{array}{c}\text { Higher water level and low water } \\
\text { level }\end{array}$ \\
\hline
\end{tabular}

In contrast to the development of the traditional hillslopes gullies, the gully lateral erosion was a more prevalent phenomenon in the reservoir riparian zone than the gully downcutting. The difference in $W / D$ reported in these studies may be due to different erosion mechanisms and erosion forces [26]. The erosion mechanism of the hillslopes gully erosion is generally overland flow shear stress exceeding the resisting forces [20,40,41]. Eroding force and gully head position are influenced by the slope grade and the catchment area above the gully head [20,42]. Hillslope gullies are mainly expanded by gully head erosion [20], which is the main trigger for the expansion of the gully system [43] and, to a lesser extent, by the scouring of the wall of the gully [44]. However, gully development in the riparian zone of manmade reservoirs is characterized by particular characteristics which are defined by interaction with other geomorphological processes in the context of water level fluctuations [45]. The hydrological regime of water level fluctuations and wave becomes the primary factor responsible for the development of erosion at the riparian zone $[19,46]$. The initiation and development of erosional landforms in the riparian zone of the reservoir show a seasonal character related to reservoir water level fluctuations (Figure 3). Gully erosion of the riparian zone is usually jointly triggered or accelerated by the extreme rainfall events, wave, gravity, and water level fluctuation. Moreover, the wave and water level fluctuation induce accelerated gully-side erosion, which is represented as gully wall failure (Figure 5).

\subsection{Geomorphological Role of Gully Erosion in Bank Erosion}

The main geomorphologic processes in the riparian zone are wave erosion, bluff erosion and landslides, cliff retreat, sheet erosion, and aeolian processes [15,45-47]. Accelerated gully development has been observed in the manmade reservoirs shore [48,49]. For instance, an increase in the volume of gullies formed in loess-like sediment is two to three times greater than the degradation of the shoreline due to the abrasion processes of overland flow in the Kamsk reservoir [50]. The development of a gully in a reservoir bank may be linked to those geomorphological processes controlled by the fluctuations in the water level of the reservoirs $[45,50]$. Moreover, gullying is important to the landform reconstruction of the riparian zone as a mechanism for slope retreat. The landform features of the gully erosion include V-shaped cutting profile in the high and steep slopes of water bodies or large river valleys in different morphoclimatic zones [45,51]. These landforms 
were evolved following the erosion by surface runoff and then underwent accelerated development by the wave scouring and flooding disturbance (Figure $4 \mathrm{~b}$ ). They may quickly evolve in one storm event as a result of the increased erosion rate caused by fluctuating water levels. In addition, the shore erosion processes, especially the gully erosion, have led to a decrease in the erosion base level and the accelerated retreat of reservoir bank scarp edges $[45,50]$. However, the function, form, and effect of riparian gully erosion on the bank retreat is different under different reservoir water level (Table 3).

As shown in Figures 4 and 5, gully mouths were submerged in periods of higher water level or flood event. The scouring of the shore slopes by the waves has resulted in the formation of shore scarps of different heights. The failure of ground blocks over wave-cut notches induced retrogressive erosion in the gully bottoms. Thus, there is a transition of gullies from a state of decay to a growth stage at high reservoir water levels [45]. The development of bank gullies on the shore zone of the Bratsk Reservoir indicated that the reservoir water level fluctuation plays a critical role in the geomorphological processes of the reservoir shoreline [50]. Overall, riparian bank gullies are commonly related to the relatively concentrated runoff path; a system of scattered and moving forward gullies on the riparian zone can merge together to form a continuously eroding gully [28]. When the erodible soils exist, the broad gully head can quickly retreat to the mountainous slopes and higher water level zone, which is shown in the schematic diagram of channel evolution in Figure 6. The initial conditions of gully erosion and bank retreat include the effects of internal and external factors $[40,52,53]$. At the same time, it also has long-term factors such as climate, geology, material composition, and topography, and short-term influencing factors such as rainfall, flood process, vegetation cover, and land use [54-56].

\section{Conclusions}

Bank erosion in the riparian zone of the Three Gorges Reservoir has been intensified by the combined effect of hillslope-concentrated flows and riverine streams. The processes of bank erosion in the riparian zone were well evidenced in the geomorphic features (gullies) developed in a typical fine-grained riparian zone. Both upland flows and flood tides were effective in causing significant soil erosion through gullying and souring processes. However, the relative contributions of these two physical processes differed spatially and temporally. Deep flows originating from upland hillslopes contributed to form large deepsituated gullies with high amounts of soil loss. Though of relatively small quantity and low detachment power, shallow concentrated overland flows developed on the upper riparian zone were proven to be essential in gully initiation and, consequently, large quantities of bank materials were detached by flood tides and removed by streams. Subsequent repeated functions of rainfall drop, overland flow, and flood pulses rendered the formed gully area the most vulnerable for erosion and sediment loss.

Author Contributions: Conceptualization and methodology, Y.B., Q.T. and X.H.; formal analysis, J.L.; investigation, Y.B., Q.T. and Y.H.; data curation, Y.Y. and J.L.; writing — original draft preparation, Y.B. and Q.T.; writing—review and editing, X.H., J.W. and Q.T.; funding acquisition, Y.B., X.H. and J.W. All authors have read and agreed to the published version of the manuscript.

Funding: This research was funded by the National Natural Science Foundation of China, grant number 41977075, 41771320, U2040207, Science Fund for Distinguished Young Scholars of Chongqing, grant number cstc2019jcyjjqX0025 and cstc2021jcyj-jqX0026.

Institutional Review Board Statement: Not applicable.

Informed Consent Statement: Not applicable.

Data Availability Statement: Not applicable.

Conflicts of Interest: The authors declare no conflict of interest. 


\section{References}

1. Hupp, C.R.; Osterkamp, W. Riparian vegetation and fluvial geomorphic processes. Geomorphology 1996, 14, 277-295. [CrossRef]

2. Lane, S.N.; Tayefi, V.; Reid, S.C.; Yu, D.; Hardy, R.J. Interactions between sediment delivery, channel change, climate change and flood risk in a temperate upland environment. Earth Surf. Process. Landf. 2006, 32, 429-446. [CrossRef]

3. Ta, W.; Jia, X.; Wang, H. Channel deposition induced by bank erosion in response to decreased flows in the sand-banked reach of the upstream Yellow River. Catena 2013, 105, 62-68. [CrossRef]

4. Baniya, M.B.; Asaeda, T.; Fujino, T.; Jayasanka, S.M.D.H.; Muhetaer, G.; Li, J. Mechanism of Riparian Vegetation Growth and Sediment Transport Interaction in Floodplain: A Dynamic Riparian Vegetation Model (DRIPVEM) Approach. Water 2019, 12, 77. [CrossRef]

5. Bull, L.J. Magnitude and variation in the contribution of bank erosion to the suspended sediment load of the River Severn, UK. Earth Surf. Proc. Land. 1997, 22, 1109-1123. [CrossRef]

6. Florsheim, J.; Mount, J.F.; Chin, A. Bank Erosion as a Desirable Attribute of Rivers. BioScience 2008, 58, 519-529. [CrossRef]

7. Walling, D.E.; Collins, A.L. Suspended sediment sources in British rivers. In Sediment Budgets 1, Proceedings of the Symposium S1 Held during the Seventh IAHS Scientific Assembly, Foz do Iguaçu, Brazil, 3-9 April 2005; Walling, D.E., Horowitz, A.J., Eds.; IAHS Press: Wallingford, UK, 2005.

8. Kronvang, B.; Andersen, H.E.; Larsen, S.E.; Audet, J. Importance of bank erosion for sediment input, storage and export at the catchment scale. J. Soils Sediments 2012, 13, 230-241. [CrossRef]

9. Owens, P.N.; Batalla, R.J.; Collins, A.J.; Gomez, B.; Hicks, D.M.; Horowitz, A.J.; Kondolf, G.M.; Marden, M.; Page, M.J.; Peacock, D.H.; et al. Fine-grained sediment in river systems: Environmental significance and management issues. River Res. Appl. 2005, 21, 693-717. [CrossRef]

10. Stover, S.; Montgomery, D. Channel change and flooding, Skokomish River, Washington. J. Hydrol. 2001, 243, 272-286. [CrossRef]

11. Dosskey, M.G.; Vidon, P.; Gurwick, N.P.; Allan, C.J.; Duval, T.P.; Lowrance, R. The Role of Riparian Vegetation in Protecting and Improving Chemical Water Quality in Streams. J. Am. Water Resour. Assoc. 2010, 46, 261-277. [CrossRef]

12. Mander, Ü.; Hayakawa, Y.; Kuusemets, V. Purification processes, ecological functions, planning and design of riparian buffer zones in agricultural watersheds. Ecol. Eng. 2005, 24, 421-432. [CrossRef]

13. Stutter, M.I.; Chardon, W.J.; Kronvang, B. Riparian Buffer Strips as a Multifunctional Management Tool in Agricultural Landscapes: In-troduction. J. Environ. Qual. 2012, 41, 297-303. [CrossRef] [PubMed]

14. Osterkamp, W.R.; Hupp, C.R. Fluvial processes and vegetation-Glimpses of the past, the present, and perhaps the future. Geomorphology 2010, 116, 274-285. [CrossRef]

15. Bao, Y.; Gao, P.; He, X. The water-level fluctuation zone of Three Gorges Reservoir-A unique geomorphological unit. Earth Sci. Rev. 2015, 150, 14-24. [CrossRef]

16. Bao, Y.; Tang, Q.; He, X.; Hu, Y.; Zhang, X. Soil erosion in the riparian zone of the Three Gorges Reservoir, China. Hydrol. Res. 2013, 46, 212-221. [CrossRef]

17. Fu, B.J.; Wu, B.F.; Lu, Y.H.; Xu, Z.H.; Cao, J.H.; Niu, D.; Yang, G.S.; Zhou, Y.M. Three Gorges Project: Efforts and challenges for the environment. Prog. Phys. Geog. 2010, 34, 741-754. [CrossRef]

18. Zhang, Q.; Lou, Z. The environmental changes and mitigation actions in the Three Gorges Reservoir region, China. Environ. Sci. Policy 2011, 14, 1132-1138. [CrossRef]

19. Tang, Q.; Bao, Y.H.; He, X.B.; Fu, B.J.; Collins, A.L.; Zhang, X.B. Flow regulation manipulates contemporary seasonal sedimentary dynamics in the reservoir fluctuation zone of the Three Gorges Reservoir, China. Sci. Total Environ. 2016, 548-549, 410-420. [CrossRef] [PubMed]

20. Oparaku, L.A.; Iwar, R.T. Relationships between average gully depths and widths on geological sediments underlying the Idah-Ankpa Plateau of the North Central Nigeria. Int. Soil Water Conse. 2018, 6, 43-50. [CrossRef]

21. Kaczmarek, H.; Mazaeva, O.; Kozyreva, E.; Babicheva, V.; Tyszkowski, S.; Rybchenko, A.A.; Brykała, D.; Bartczak, A.; Słowiński, M. Impact of large water level fluctuations on geomorphological processes and their interactions in the shore zone of a dam reservoir. J. Great Lakes Res. 2016, 42, 926-941. [CrossRef]

22. Valentin, C.; Poesen, J.; Li, Y. Gully erosion impacts, factors and control. Catena 2005, 63, 132-153. [CrossRef]

23. Zgłobicki, W.; Poesen, J.; Cohen, M.; Del Monte, M.; García-Ruiz, J.M.; Ionita, I.; Niacsu, L.; Machová, Z.; Martín-Duque, J.F.; Nadal-Romero, E.; et al. The Potential of Permanent Gullies in Europe as Geomorphosites. Geoheritage 2017, 11, 217-239. [CrossRef]

24. Morgan, R.; Mngomezulu, D. Threshold conditions for initiation of valley-side gullies in the Middle Veld of Swaziland. Catena 2003, 50, 401-414. [CrossRef]

25. Holbrook, J.; Schumm, S.A. Geomorphic and sedimentary response of rivers to tectonic deformation: A brief review and critique of a tool for recognizing subtle epeirogenic deformation in modern and ancient settings. Tectonophysics 1999, 305, $287-306$. [CrossRef]

26. Vandekerckhove, L.; Poesen, J.; Wijdenes, D.O.; Gyssels, G.; Beuselinck, L.; de Luna, E. Characteristics and controlling factors of bank gullies in two semi-arid mediterranean environments. Geomorphology 2000, 33, 37-58. [CrossRef]

27. Brooks, A.P.; Shellberg, J.G.; Knight, J.; Spencer, J. Alluvial gully erosion: An example from the Mitchell fluvial megafan, Queensland, Australia. Earth Surf. Process. Landf. 2009, 34, 1951-1969. [CrossRef] 
28. Shellberg, J.G.; Spencer, J.; Brooks, A.P.; Pietsch, T.J. Degradation of the Mitchell River fluvial megafan by alluvial gully erosion in-creased by post-European land use change, Queensland, Australia. Geomorphology 2016, 266, 105-120. [CrossRef]

29. Shellberg, J.; Brooks, A.; Spencer, J.; Ward, D. The hydrogeomorphic influences on alluvial gully erosion along the Mitchell River fluvial megafan. Hydrol. Process. 2012, 27, 1086-1104. [CrossRef]

30. Erskine, W.D.; Melville, M.D. Sediment movement in a discontinuous gully system at Boro Creek, Southern Tablelands, N.S.W. In Drainage Basin Erosion and Sedimentation, Proceedings of the Conference on Erosion, Transportation and Sedimentation in Australian Drainage Basins, Newcastle, NSW, Australia, 14-17 May 1984; Loughran, R.J., Ed.; University of Newcastle and the Soil Conservation Service of N.S.W.: Newcastle, NSW, Australia, 1984.

31. Yibeltal, M.; Tsunekawa, A.; Haregeweyn, N. Morphological characteristics and topographic thresholds of gullies in different agroecological environments. Geomorphology 2019, 341, 15-27. [CrossRef]

32. Vandekerckhove, L.; Poesen, J.; Govers, G. Medium-term gully headcut retreat rates in Southeast Spain determined from aerial photographs and ground measurements. Catena 2003, 50, 329-352. [CrossRef]

33. Capra, A.; Porto, P.; Scicolone, B. Relationships between rainfall characteristics and ephemeral gully erosion in a cultivated catchment in Sicily (Italy). Soil Tillage Res. 2009, 105, 77-87. [CrossRef]

34. Li, Z.; Zhang, Y.; Zhu, Q.; He, Y.; Yao, W. Assessment of bank gully development and vegetation coverage on the Chinese Loess Plateau. Geomorphology 2015, 228, 462-469. [CrossRef]

35. Castillo, C.; Gómez, J. A century of gully erosion research: Urgency, complexity and study approaches. Earth Sci. Rev. 2016, 160, 300-319. [CrossRef]

36. Frankl, A.; Poesen, J.; Deckers, J.; Haile, M.; Nyssen, J. Gully head retreat rates in the semi-arid highlands of Northern Ethiopia. Geomorphology 2012, 173-174, 185-195. [CrossRef]

37. Frankl, A.; Poesen, J.; Haile, M.; Deckers, J.; Nyssen, J. Quantifying long-term changes in gully networks and volumes in dryland envi-ronments: The case of Northern Ethiopia. Geomorphology 2013, 201, 254-263. [CrossRef]

38. Zucca, C.; Canu, A.; Della Peruta, R. Effects of land use and landscape on spatial distribution and morphological features of gullies in an agropastoral area in Sardinia (Italy). Catena 2006, 68, 87-95. [CrossRef]

39. Wu, H.; Xu, X.; Zheng, F.; Qin, C.; He, X. Gully morphological characteristics in the loess hilly-gully region based on 3D laser scanning technique. Earth Surf. Process. Landf. 2018, 43, 1701-1710. [CrossRef]

40. Montgomery, D.; Dietrich, W. Where do channels begin? Nature 1988, 336, 232-234. [CrossRef]

41. Prosser, I.P.; Chappell, J.; Gillespie, R. Holocene valley aggradation and gully erosion in headwater catchments, south-eastern highlands of Australia. Earth Surf. Process. Landf. 1994, 19, 465-480. [CrossRef]

42. Knapen, A.; Poesen, J.; Govers, G.; Gyssels, G.; Nachtergaele, J. Resistance of soils to concentrated flow erosion: A review. Earth Sci. Rev. 2007, 80, 75-109. [CrossRef]

43. Montgomery, D.R.; Dietrich, W.E. Channel Initiation and the Problem of Landscape Scale. Science 1992, 255, 826-830. [CrossRef]

44. Oostwoud Wijdenes, D.; Bryan, R. Gully-head erosion processes on a semi-arid valley floor in Kenya: A case study into temporal varia-tion and sediment budgeting. Earth Surf. Proc. Land. 2001, 26, 911-933. [CrossRef]

45. Mazaeva, O.; Babicheva, V.; Kozyreva, E. Gully development on large dam reservoir shores: Dynamics, interaction, and mechanisms. Phys. Geogr. 2019, 41, 195-216. [CrossRef]

46. Poesen, J.; Nachtergaele, J.; Verstraeten, G.; Valentin, C. Gully erosion and environmental change: Importance and research needs. Catena 2003, 50, 91-133. [CrossRef]

47. Collins, B.D.; Sitar, N. Processes of coastal bluff erosion in weakly lithified sands, Pacifica, California, USA. Geomorphology 2008, 97, 483-501. [CrossRef]

48. Vilmundardóttir, O.; Magnússon, B.; Gísladóttir, G.; Thorsteinsson, T. Shoreline erosion and aeolian deposition along a recently formed hydro-electric reservoir, Blöndulón, Iceland. Geomorphology 2010, 114, 542-555. [CrossRef]

49. Burkard, M.B.; Kostaschuk, R.A. Patterns and controls of gully growth along the shoreline of Lake Huron. Earth Surf. Process. Landf. 1997, 22, 901-911. [CrossRef]

50. Mazaeva, O.; Pellinen, V.; Janicki, G. Development of bank gullies on the shore zone of the Bratsk Reservoir (Russia). Ann. UMCS Geogr. Geol. Miner. Petrogr. 2014, 69, 117-133. [CrossRef]

51. Smolska, E. Development of gullies and sedimentjans in last-glacial areas on the example of the Suwalki Lakeland (NE Poland). Catena 2007, 71, 122-131. [CrossRef]

52. Leyland, J.; Darby, S.E. An empirical-conceptual gully evolution model for channelled sea cliffs. Geomorphology 2008, 102, 419-434 [CrossRef]

53. Schumm, S.A.; Hadley, R.F. Arroyos and the semiarid cycle of erosion [Wyoming and New Mexico]. Am. J. Sci. 1957, 255, 161-174. [CrossRef]

54. Tucker, G.E.; Arnold, L.; Bras, R.L.; Flores, H.; Istanbulluoglu, E.; Sólyom, P. Headwater channel dynamics in semiarid rangelands, Colorado high plains, USA. Geol. Soc. Am. Bull. 2006, 118, 959-974. [CrossRef]

55. Schumm, S.A.; Lichty, R.W. Space, time and causality in geomorphology. Am. J. Sci. 1965, 263, 110-119. [CrossRef]

56. Phillips, J.D. Relative importance of intrinsic, extrinsic, and anthropic factors in the geomorphic zonation of the Trinity River, Texas. J. Am. Water Resour. Assoc. 2010, 46, 807-823. 